\title{
Preparation and Diels-Alder/cross coupling reactions of a 2-diethanolaminoboron-substituted 1,3-diene
}

\author{
Liqiong Wang, Cynthia S. Day, Marcus W. Wright and Mark E. Welker
}

\author{
Preliminary Communication \\ Address: \\ Department of Chemistry, Wake Forest University, P.O. Box 7486, \\ Winston-Salem, NC 27109 (USA) \\ Email: \\ Mark E. Welker* - welker@wfu.edu \\ * Corresponding author \\ Keywords: \\ cross coupling; Diels-Alder; organoboron
}

Open Access

Beilstein Journal of Organic Chemistry 2009, 5, No. 45 doi:10.3762/bjoc. 5.45

Received: 02 July 2009

Accepted: 08 September 2009

Published: 21 September 2009

Associate Editor: I. Marek

(ㄷ) 2009 Wang et al; licensee Beilstein-Institut.

License and terms: see end of document.

\begin{abstract}
A 2-diethanolamine boronyl substituted 1,3-diene has been synthesized in high yield and characterized spectroscopically as well as by X-ray crystallography. This diene has then subsequently been used in a number of fast, high yielding Diels-Alder/cross coupling reactions.
\end{abstract}

\section{Introduction}

Our group [1] and the Tada group [2] independently reported the preparation and Diels-Alder reactions of pyridine cobaloxime dienyl complexes over 15 years ago. Since that time, we have reported a number of synthetic routes to these and other related types of cobalt dienyl complexes as well as their subsequent cycloaddition and demetallation chemistry [3-5], and other groups have now made use of the cycloadducts thus prepared [6] as well as the methodology [7].

We have now subsequently reported the preparation of $2-\mathrm{BF}_{3}$ substituted 1,3-butadienes and demonstrated that they can be used in sequential Diels-Alder/cross coupling reactions [8,9]. These trifluoroborate substituted dienes are stable but their organic solvent solubility is not ideal. Preparation of more highly substituted $\mathrm{BF}_{3}$ dienes also requires a transmetallation protocol which yields a Grignard- $\mathrm{BF}_{3}$ by-product which has to be separated from the desired diene [9]. To overcome these methodology challenges we have begun to prepare diethanolaminoboron substituted dienes and we communicate our first results in this area here.

\section{Results and Discussion}

The diethanolamine boronyl substituted diene $\mathbf{2}$ was obtained as white needles on a several gram scale from a simple procedure which involved preparing the Grignard reagent from chloroprene 1, adding this reagent to trimethoxyborane followed by the addition of dilute $\mathrm{HCl}$ and diethanolamine (Scheme 1). The boron substituted diene 2 thus obtained has $\mathrm{C} 1$ ( $\delta 5.23$ vs $\delta$ $5.04,4.96\left(\mathrm{~d}_{6}\right.$-DMSO) and $\mathrm{C} 3(\delta 6.31$ vs. $\delta 6.19)$ hydrogen atoms which are significantly more deshielded than the $\mathrm{BF}_{3}$ substituted diene. In the solid state (Figure 1, see Supporting Information), $\mathrm{C}(1)-\mathrm{C}(2)$ and $\mathrm{C}(2)-\mathrm{C}(3)$ bond lengths were 

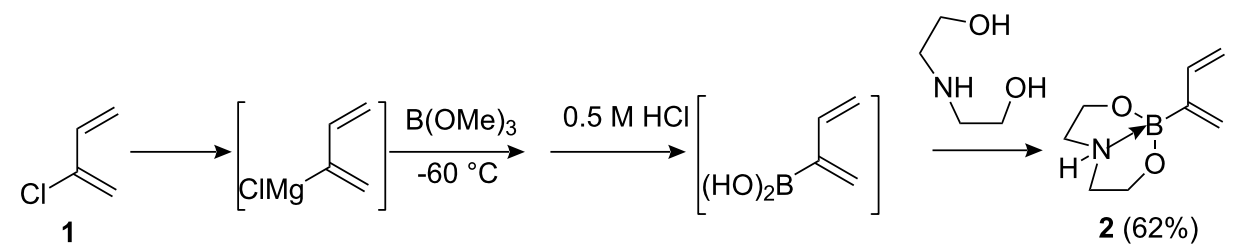

Scheme 1: Synthesis of 2-diethanolaminoborate-1,3-butadiene.

virtually identical in both dienes whereas B-C(2) $(1.609(5) \AA$ vs $1.576(13) \AA$ ) and C(3)-C(4) (1.308(6) $\AA$ vs $1.279(13) \AA)$ were significantly longer in the diethanolamine boronyl diene 2 .

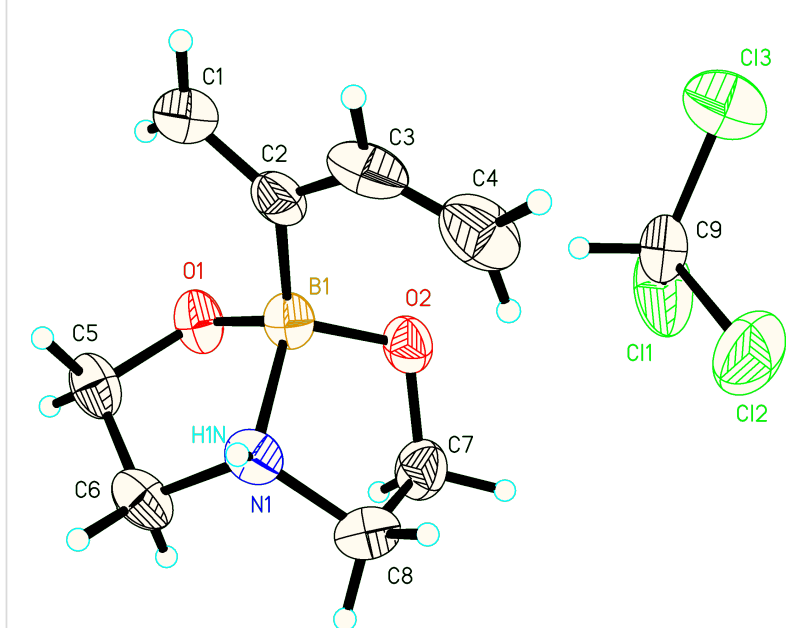

Figure 1: Molecular structure of boron substituted diene 2.

This diethanolamine boronyl diene $\mathbf{2}$ has proved to be significantly more reactive and more regioselective in Diels-Alder reactions compared to its $\mathrm{BF}_{3}$ diene counterpart (Table 1,
Scheme 2) [8]. Qualitatively, we initially noticed that whereas the $\mathrm{BF}_{3}$ diene required $16 \mathrm{~h}$ of heating at $95-100{ }^{\circ} \mathrm{C}$ in a sealed tube in toluene with $\mathrm{N}$-phenylmaleimide to obtain $>90 \%$ yield of cycloadduct, the diethanolamine boronyl diene 2 reacted with this same dienophile to afford a $98 \%$ isolated yield of cyclaooduct 4 after only $15 \mathrm{~min}$ at $25^{\circ} \mathrm{C}$ ! We tried to get more quantitative rate constant data about this Diels-Alder reaction via NMR spectroscopy but when we try to perform this reaction under pseudo first order conditions at $-10^{\circ} \mathrm{C}$, we can only say that the $t_{1 / 2}$ is less than 4 minutes. Attempts to get more accurate kinetic data by NMR at $-40{ }^{\circ} \mathrm{C}$ resulted instead in diene $\mathbf{2}$ precipitation. This diene $\mathbf{2}$ is by far the most reactive main group element substituted diene we have made in the boron or silicon substituted series to date. What is perhaps even more surprising to us is that this diene $\mathbf{2}$ is even more reactive than the most reactive cobaloxime substituted diene we ever prepared in our earlier work [10] and those cobaloxime dienes consistently favored the $s$-cis conformation in the solid state. Diene $\mathbf{2}$ is in the s-trans conformation in the solid state (Figure 1) but in this case we suspect that the preference for the $s$-trans conformer is due to intermolecular hydrogen bonding between the $\mathrm{N}-\mathrm{H}$ and one of the adjacent molecule's boronate oxygen atoms. This hydrogen bonding would make a $\mathrm{C}(2)-\mathrm{C}(3)$ dihedral angle of $50-60^{\circ}$ (on the order of those we observed in cobaloxime diene solid state structures) unfavorable. At $25^{\circ} \mathrm{C}$

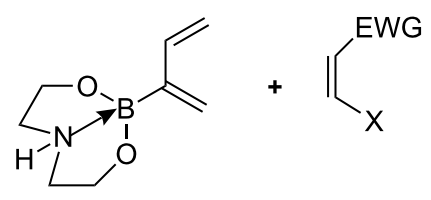

2

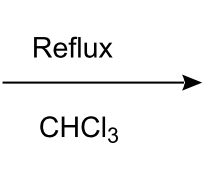<smiles></smiles>

major<smiles>[X]C1CC=C(B2OC[C@H]3CN4CCO[C@]2(C4)O3)CC1C(C)(C)C</smiles>

minor

Scheme 2: Diels-Alder reactions.

Table 1: Diels-Alder reactions of diene 2.

\begin{tabular}{clcccc} 
Product \# & Dienophile & Temp $\left({ }^{\circ} \mathrm{C}\right)$ & Time $(\mathrm{h})$ & Yield $(\%)$ & Major:Minor \\
\hline $\mathbf{3}$ & ethyl acrylate & reflux & 6 & $16.4: 1$ \\
$\mathbf{4}$ & N-phenyl maleimide & 25 & 0.25 & 98 \\
$\mathbf{5}$ & 2-methyl N-phenyl maleimide & reflux & 8 & NA
\end{tabular}


in $\mathrm{CDCl}_{3}$, we saw no evidence for the $s$-cis conformer by NOESY.

In an effort to further understand this reactivity difference, geometry-optimization with DFT using the B3LYP functional and a $6-31 \mathrm{G}(\mathrm{d})$ basis set followed by population analysis was performed using Gaussian 03 on 2-diethanolaminoboronyl-1,3butadiene (2) and its $\mathrm{BF}_{3}$ diene counterpart. 2-Diethanolaminoboronyl-1,3-butadiene has a HOMO energy of $-6.00 \mathrm{eV}$, whereas its $\mathrm{BF}_{3}$ diene counterpart has a HOMO energy of $-12.58 \mathrm{eV}$. These energies are consistent with our observations that 2-diethanolaminoboronyl-1,3-butadiene (2) is more reactive than its $\mathrm{BF}_{3}$ diene counterpart. Furthermore, a Mulliken population analysis indicates a build-up of electron density on carbons $\mathrm{C} 1$ and $\mathrm{C} 4$ of $0.15 \mathrm{e}$ and $0.14 \mathrm{e}$ respectively in 2-diethanolaminoboronyl-1,3-butadiene (2) compared to its $\mathrm{BF}_{3}$ diene counterpart, which is also consistent with our observations. In addition to enhanced Diels-Alder reaction rates, we also noted greatly improved regioselectivities (Table 1). Whereas the $\mathrm{BF}_{3}$ diene required $36 \mathrm{~h}$ of heating to $95-100{ }^{\circ} \mathrm{C}$ in a sealed tube in ethanol to provide a 3.3:1 mixture of regioisomers from reaction with ethyl acrylate, the diethanolamine boronyl diene 2 reacted with this same dienophile at reflux for $6 \mathrm{~h}$ to provide a 16.4: 1 mixture of para $(1,4)$ to meta $(1,3)$ isomers 3 in identical isolated yield. Similarly, when we used a citraconamide derivative (2-methyl $N$-phenylmaleimide), we isolated cycloadduct 5 in high yield although with reduced regioselectivity (4:1). However, the $\mathrm{BF}_{3}$ diene proved unreactive with citraconic acid derived dienophiles. This diethanolamine boronyl diene $\mathbf{2}$ once again reacted under much milder conditions and with better regioselectivity than highly reactive silicon substituted dienes we have also reported previously [11].

Lastly, in order to prove that diethanolamine boronyl diene $\mathbf{2}$ could serve as a synthon for a host of other organic dienes, we took cycloadducts $\mathbf{3}-\mathbf{5}$ and proved that they could be cross coupled efficiently to iodobenzene, 4-trifluoromethyl-1iodobenzene, and 4-iodoanisole (Table 2, Scheme 3). Cross coupled cycloadducts 6-14 were all isolated in good to excellent yield and regioselectivities observed in the original Diels-Alder reactions were maintained after cross coupling.

\begin{tabular}{|cccccc|}
\hline Table 2: Results of cross coupling reactions. \\
\hline Entry & $\begin{array}{c}\text { Cycloadduct } \\
(\#)\end{array}$ & $\mathrm{R}$ & $\begin{array}{c}\text { Yield } \\
(\%)\end{array}$ & $\begin{array}{c}\text { Isomer } \\
\text { ratio }\end{array}$ & $\begin{array}{c}\text { Product } \\
(\#)\end{array}$ \\
\hline 1 & $\mathbf{3}$ & $\mathrm{H}$ & 85 & $17.2: 1$ & $\mathbf{6}$ \\
2 & $\mathbf{3}$ & $\mathrm{CF}_{3}$ & 97 & $17.9: 1$ & $\mathbf{7}$ \\
3 & $\mathbf{3}$ & $\mathrm{OMe}$ & 80 & $18.0: 1$ & $\mathbf{8}$ \\
4 & $\mathbf{4}$ & $\mathrm{H}$ & 64 & $\mathrm{NA}$ & $\mathbf{9}$ \\
5 & $\mathbf{4}$ & $\mathrm{CF}_{3}$ & 70 & $\mathrm{NA}$ & $\mathbf{1 0}$ \\
6 & $\mathbf{4}$ & $\mathrm{OMe}$ & 60 & $\mathrm{NA}$ & $\mathbf{1 1}$ \\
7 & $\mathbf{5}$ & $\mathrm{H}$ & 58 & $3.5: 1$ & $\mathbf{1 2}$ \\
8 & $\mathbf{5}$ & $\mathrm{CF}_{3}$ & 70 & $3.4: 1$ & $\mathbf{1 3}$ \\
9 & $\mathbf{5}$ & $\mathrm{OMe}$ & 75 & $3.3: 1$ & $\mathbf{1 4}$ \\
\hline & & & & & \\
\hline
\end{tabular}

\section{Conclusion}

In conclusion, we report a simple preparation of a 2-boronyl substituted 1,3 diene which has proved to be the most reactive 2-main group element or 2-transition metal element substituted diene for Diels-Alder reactions that we have prepared to date. We have also demonstrated that this boron-substituted diene can serve as a synthon for a host of organic dienes via cross coupling reactions which we performed on Diels-Alder reaction cycloadducts.

\section{Experimental}

Preparation of 1,3-butadiene-2-diethanolamine boronate 2: A mixture of magnesium $(1.0 \mathrm{~g}, 41.1 \mathrm{mmol}), 1,2$-dibromoethane $(0.5 \mathrm{~mL})$, and THF $(10 \mathrm{~mL})$ was refluxed under nitrogen for $15 \mathrm{~min}$ to activate the magnesium. To the mixture anhydrous zinc chloride $(0.6 \mathrm{~g})$ in THF $(60 \mathrm{~mL})$ was added and reflux was continued for another $15 \mathrm{~min}$. 2-Chloro-1,3-butadiene (4.9 $\mathrm{mL}, 25 \mathrm{mmol}$ ) (density $0.915 \mathrm{~g} / \mathrm{mL}, 50 \%$ in xylene) and $1,2-$ dibromoethane $(0.95 \mathrm{~g}, 5 \mathrm{mmol})$ in THF $(30 \mathrm{~mL})$ were added dropwise over a period of $30 \mathrm{~min}$. This addition was controlled so as to bring the mixture into a gentle reflux. The color of the contents changed gradually from grayish white to greenish black. The mixture was heated to reflux for an additional 30 min after completion of the addition. The Grignard reagent thus obtained was immediately added dropwise to a solution of trimethoxyborane $(4.25 \mathrm{~mL}, 38.5 \mathrm{mmol})$ in THF (25 mL) using a double-ended needle. The addition was controlled in such a

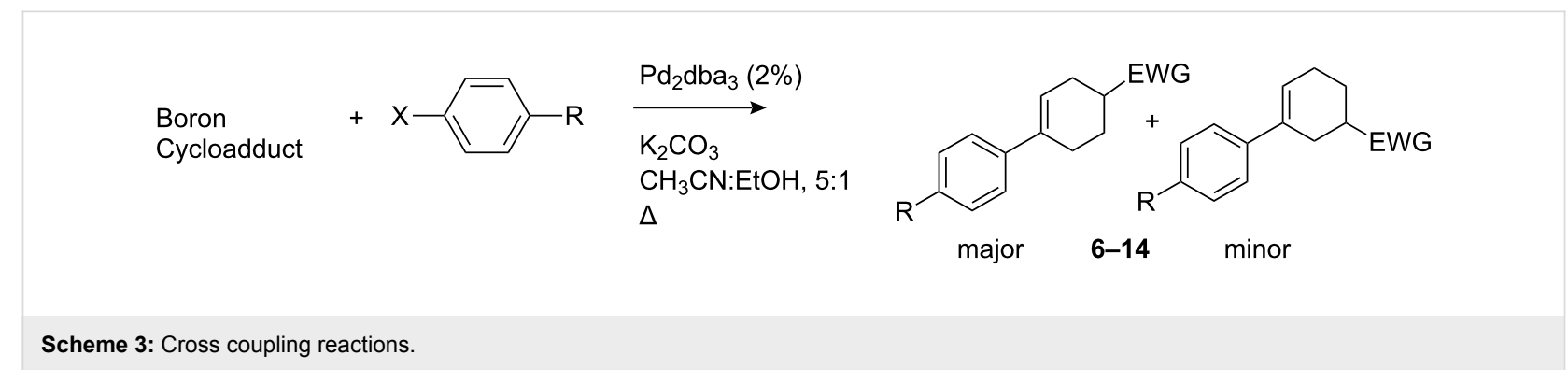


way that the internal temperature of the mixture was maintained below $-60{ }^{\circ} \mathrm{C}$ all the time. After completion of the addition, the solution was allowed to warm to room temperature quickly. The cloudy gray colored reaction mixture was stirred for $1 \mathrm{~h}$. To the resulting mixture at room temperature, $0.5 \mathrm{M}$ $\mathrm{HCl}$ solution $(100 \mathrm{~mL})$ was added. The reaction mixture was extracted with $\mathrm{Et}_{2} \mathrm{O}(2 \times 75 \mathrm{~mL})$. The combined colorless clear organic layers were dried over $\mathrm{MgSO}_{4}$, and the volatiles were removed by a rotary evaporator $\left(30^{\circ} \mathrm{C}, 20\right.$ Torr $)$ to yield the dieneboronic acid. The boronic acid was added at once to a solution of diethanolamine ( 0.8 equiv, $22.5 \mathrm{mmol}, 8.411 \mathrm{~g}$ ) dissolved in THF $(100 \mathrm{~mL})$. Sodium sulfate $(8 \mathrm{~g})$ was added and refluxed for $6 \mathrm{~h}$. At the end of the reaction, the flask was cooled to room temperature. Solid $\mathrm{Na}_{2} \mathrm{SO}_{4}$ was separated from the solution by filtration. The solution was reduced by $50 \mathrm{~mL}$ using a rotary evaporator. A cold bath of $-30{ }^{\circ} \mathrm{C}$ was used to induce crystallization. After $4 \mathrm{~h}$, the solid was filtered and washed with cold chloroform. The product $\mathbf{2}$ was obtained as white needles (2.40 g, $14.4 \mathrm{mmol}, 62.4 \%) .{ }^{1} \mathrm{H}$ NMR $(300 \mathrm{MHz}$, $\left.\mathrm{CDCl}_{3}\right) \delta 6.51(\mathrm{dd}, J=17.9,10.9 \mathrm{~Hz}, 1 \mathrm{H}-\mathrm{H} 3), 5.46-5.40(\mathrm{~m}$, $3 \mathrm{H}), 4.98$ (dd, $J=17.9,1.9 \mathrm{~Hz}, 1 \mathrm{H}-\mathrm{H} 4), 5.18$ (s, 1H-H7), 4.05 (m, 2H-H5,8), 3.89 (m, 2H-H5,8), 3.31 (m, 2H-H6,9), 2.76 (m, $2 \mathrm{H}-\mathrm{H} 6,9){ }^{13} \mathrm{C} \mathrm{NMR}\left(300, \mathrm{MHz}, \mathrm{CDCl}_{3}\right) \delta 143.6-\mathrm{C} 3,124.3-\mathrm{C} 4$, 114.6-C1, 63.4-C5,8, 52.1-C6,9, the signal of carbon $\mathrm{C} 2$ next to a tetravalent boron is generally not observed due to quadrupolar broadening [12]. Elemental anal. calcd for $\mathrm{C}_{8} \mathrm{H}_{14} \mathrm{BNO}_{2}$ : C, 57.53; H, 8.45. Found: 57.06, 8.44.

\section{Representative Diels-Alder procedure}

Preparation of Diels-Alder product 3: Diene 2 (0.167 g, 1 $\mathrm{mmol})$ and ethyl acrylate $(0.700 \mathrm{~g}, 7 \mathrm{mmol})$ were dissolved in chloroform $(15 \mathrm{~mL})$ in a round bottomed flask and refluxed for $6 \mathrm{~h}$. The white product was precipitated with pentane $(150 \mathrm{~mL})$ and obtained by vacuum filtration, $(0.224 \mathrm{~g}, 0.84 \mathrm{mmol}, 84 \%)$. 3: ${ }^{1} \mathrm{H}$ NMR $\left(300 \mathrm{MHz}, \mathrm{CDCl}_{3}\right) \delta 5.91(\mathrm{~m}, 1 \mathrm{H}), 4.86(\mathrm{~s}, 1 \mathrm{H})$, $4.12(\mathrm{q}, J=7.25,2 \mathrm{H}), 3.97(\mathrm{~m}, 2 \mathrm{H}), 2.893(\mathrm{~m}, 2 \mathrm{H}), 3.224(\mathrm{~m}$, $2 \mathrm{H}), 2.79(\mathrm{~m}, 2 \mathrm{H}), 2.48(\mathrm{~m}, 1 \mathrm{H}), 2.23(\mathrm{~m}, 2 \mathrm{H}), 2.11(\mathrm{~m}, 2 \mathrm{H})$, $1.99(\mathrm{~m}, 1 \mathrm{H}), 1.76(\mathrm{~s}, 1 \mathrm{H}), 1.25(\mathrm{t}, J=7.25,3 \mathrm{H}) .{ }^{13} \mathrm{C} \mathrm{NMR}$ $\left(300 \mathrm{MHz}, \mathrm{CDCl}_{3}\right) \delta$ Major isomer: 176.7, 139.9 (=C-B), $126.9,62.85,62.81,60.0,51.2,40.1,39.8,28.6,26.4,25.9$, 14.0. Minor isomer selected resonances: 176.2, 127.6, 24.7, 24.6. Major isomer: minor isomer $=16.4: 1$. Elemental anal. calcd. for $\mathrm{C}_{13} \mathrm{H}_{22} \mathrm{BNO}_{4}$ : C, 58.45; H, 8.30. Found: 58.17, 8.32.

\section{Representative Suzuki coupling procedure}

General procedure: Boron compounds and iodoaromatic compounds were added to a $\mathrm{N}_{2}$ flushed flask with $\mathrm{Pd}_{2}(\mathrm{dba})_{3}$ and $\mathrm{K}_{2} \mathrm{CO}_{3}$ in acetonitrile and ethanol $(30 \mathrm{~mL})$. The mixture was refluxed for $36 \mathrm{~h}$ and cooled to room temperature. The solution was filtered through silica gel to remove catalysts. The filtrate was quenched with water $(50 \mathrm{~mL})$ and extracted with
$\mathrm{Et}_{2} \mathrm{O}(4 \times 50 \mathrm{~mL})$. The combined organic layers were dried over $\mathrm{MgSO}_{4}$ and volatiles were removed by rotary evaporation. The resulting cross-coupled cycloadduct residue was purified by flash chromatography (ethyl ether:hexane $=1: 1$ ). Optimization of conditions: $2 \% \quad \mathrm{Pd}_{2}(\mathrm{dba})_{3}$ [Tris(dibenzylideneacetone)dipalladium (0)], acetonitrile:ethanol $=5: 1$, boron cycloadduct:iodoaromatic compounds $=1: 2, \mathrm{~K}_{2} \mathrm{CO}_{3}$ (3 equiv) reaction time: $36 \mathrm{~h}$.

Preparation of 6-(4-methoxyphenyl)-3a-methyl-2-phenyl3a,4,7,7a-tetrahydro-1H-isoindole-1,3(2H)-dione (14): Following the general procedure, 4-iodoanisole $(0.234 \mathrm{~g}, 1$ $\mathrm{mmol})$ and 5 (0.178 g, $0.5 \mathrm{mmol})$ were added along with $\mathrm{Pd}_{2}(\mathrm{dba})_{3}(10 \mathrm{mg})$ and $\mathrm{K}_{2} \mathrm{CO}_{3}(0.207 \mathrm{~g}, 1.5 \mathrm{mmol})$ to a flask under $\mathrm{N}_{2}(30 \mathrm{~mL}$ acetonitrile and ethanol). The flask was heated and refluxed for $36 \mathrm{~h}$. The resulting brown oily crude product mixture was subjected to flash chromatography to yield the cross-coupled product as a white solid $(0.134 \mathrm{~g}, 0.39 \mathrm{mmol}$, 78\%). 14: ${ }^{1} \mathrm{H}$ NMR (300 MHz, $\mathrm{CDCl}_{3}$ ) $\delta$ Major isomer: 7.38 $(\mathrm{d}, J=7.5 \mathrm{~Hz}, 2 \mathrm{H}), 7.31(\mathrm{~d}, J=8.7 \mathrm{~Hz}, 2 \mathrm{H}), 7.26(\mathrm{~m}, 1 \mathrm{H}), 7.13$ $(\mathrm{d}, J=7.5 \mathrm{~Hz}, 2 \mathrm{H}), 6.85(\mathrm{~d}, J=8.8 \mathrm{~Hz}, 2 \mathrm{H}), 6.1(\mathrm{~m}, 1 \mathrm{H}), 3.80$ (s, 3H), $3.25(\mathrm{dd}, J=15.4,2.4 \mathrm{~Hz}, 1 \mathrm{H}), 2.99(\mathrm{dd}, J=6.5,2.4$ $\mathrm{Hz}, 1 \mathrm{H}), 2.86(\mathrm{dd}, J=15.4,6.5 \mathrm{~Hz}, 1 \mathrm{H}), 2.61$ (ddt, $J=15.4$, 6.5, $2.4 \mathrm{~Hz}, 1 \mathrm{H}), 2.16(\mathrm{dd}, J=15.4,2.4 \mathrm{~Hz}, 1 \mathrm{H}), 1.50$ (s, 3H). Minor isomer selected resonances: $3.15(\mathrm{~d}, J=15.4), 2.44$ (m), $2.30(\mathrm{~m}) .{ }^{13} \mathrm{C} \mathrm{NMR}\left(300 \mathrm{MHz}, \mathrm{CDCl}_{3}\right) \delta 182.3,178.5$, $159.5,139.8,133.1,132.4,129.4,128.8,127.0,126.8,122.0$, 114.3, 55.6, 48.4, 45.1, 36.7, 30.6, 25.9. Elemental anal. calcd for $\mathrm{C}_{22} \mathrm{H}_{21} \mathrm{NO}_{3}$ : C, 76.06; H, 6.09. Found: 76.34, 6.31.

\section{Supporting Information}

\section{Supporting Information File 1 \\ ${ }^{1} \mathrm{H}$ and ${ }^{13} \mathrm{C}$ NMR spectra of compounds $\mathbf{2 - 1 4}$. \\ [http://www.beilstein-journals.org/bjoc/content/ supplementary/1860-5397-5-45-S1.doc] \\ Supporting Information File 2 \\ Experimental procedures for compounds 4-13. \\ [http://www.beilstein-journals.org/bjoc/content/ supplementary/1860-5397-5-45-S2.doc]}

\section{Acknowledgments}

We thank the National Science Foundation for their support of this work (CHE-0450722 and CHE-0749759) and the NMR instrumentation used to characterize the compounds reported here. The UNC Center for Mass Spectrometry performed high resolution mass spectral analyses. We thank Fred Salsbury of the Department of Physics for performing the DFT calculations discussed in this manuscript. 


\section{References}

1. Smalley, T. L.; Wright, M. W.; Garmon, S. A.; Welker, M. E.; Rheingold, A. L. Organometallics 1993, 12, 998-1000. doi:10.1021/om00028a006

2. Tada, M.; Shimizu, T. Bull. Chem. Soc. Jpn. 1992, 65, 1252-1256. doi:10.1246/bcsj.65.1252

3. Pickin, K. A.; Kindy, J. M.; Day, C. S.; Welker, M. E. J. Organomet. Chem. 2003, 681, 120-133. doi:10.1016/S0022-328X(03)00587-4

4. Welker, M. E. Curr. Org. Chem. 2001, 5, 785-807. doi:10.2174/1385272013375175

5. Tucker, C. J.; Welker, M. E.; Day, C. S.; Wright, M. W. Organometallics 2004, 23, 2257-2262. doi:10.1021/om040010z

6. Miyaki, Y.; Onishi, T.; Ogoshi, S.; Kurosawa, H. J. Organomet. Chem. 2000, 616, 135-139. doi:10.1016/S0022-328X(00)00583-0

7. Chai, C. L. L.; Johnson, R. C.; Koh, J. Tetrahedron 2002, 58, 975-982. doi:10.1016/S0040-4020(01)01160-7

8. De, S.; Welker, M. E. Org. Lett. 2005, 7, 2481-2484. doi:10.1021/ol050794s

9. De, S.; Day, C.; Welker, M. E. Tetrahedron 2007, 63, 10939-10948. doi:10.1016/j.tet.2007.08.063

10. Wright, M. W.; Smalley, T. L.; Welker, M. E.; Rheingold, A. L. J. Am. Chem. Soc. 1994, 116, 6777-6791. doi:10.1021/ja00094a037

11. Pidaparthi, R. R.; Welker, M. E.; Day, C. S.; Wright, M. W. Org. Lett. 2007, 9, 1623-1626. doi:10.1021/ol070089e

12. Darses, S.; Guillaume, M.; Genet, J.-P. Eur. J. Org. Chem. 1999, 8 , 1875-1883. doi:10.1002/(SICI)1099-0690(199908)1999:8<1875::AID-EJOC1875>3 .3.CO;2-N

\section{License and Terms}

This is an Open Access article under the terms of the Creative Commons Attribution License (http://creativecommons.org/licenses/by/2.0), which permits unrestricted use, distribution, and reproduction in any medium, provided the original work is properly cited.

The license is subject to the Beilstein Journal of Organic Chemistry terms and conditions:

(http://www.beilstein-journals.org/bjoc)

The definitive version of this article is the electronic one which can be found at: doi:10.3762/bjoc.5.45 